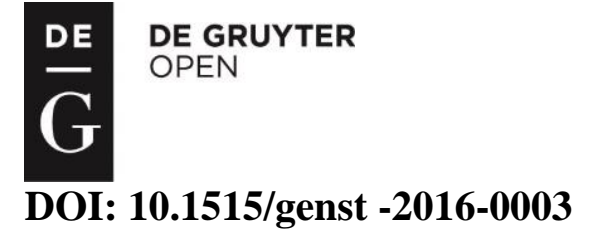

\title{
THE UNCONTROLLABLE MNEMONIC FRAGMENTS WITHIN CONSCIOUSNESS REFLECTING OPHELIA'S AND LADY MACBETH'S DISTURBED MINDS
}

\author{
NESLIHAN EKMEKÇIOĞLU \\ University of Çankaya \\ Yukarıyurtçu, Eskişehir Yolu 29. Km, Mimar Sinan Caddesi No.4, \\ 06790 Etimesgut/Ankara, Turkey \\ mayneslie@turk.net
}

\begin{abstract}
Memory plays an important role in most of Shakespeare's plays. Shakespeare delves into the dark realms of human consciousness to reflect the disturbed minds and gnawing consciences of his characters with a profound psychological insight into the human psyche. Time, memory, madness and death seem to be the basic issues dealt with in his canon. My paper will address the uncontrollable mnemonic fragments within the human consciousness which reflect past traumas, fears and disturbances and will examine the cases of Ophelia and Lady Macbeth from a feminist reading of women.
\end{abstract}

Keywords: consciousness, memory, patriarchy, suppression, trauma.

\section{Introduction}

In Greek mythology, Mnemosyne was the goddess of memory and was considered to be the source from which all human culture such as art, history, music and science sprang, whereas her sister, Lesmosyne, was the 
goddess of oblivion who presided over forgetfulness and forgetting. In his discussion of 'Poetic Wisdom', Giambattista Vico wrote that "imagination is nothing but the springing up again of reminiscences" (cited in Rickard 1999:1). Memory could be regarded both as a creative force for the human imagination and as a paralysing power for the human consciousness and intellect.

Memory seems to be of crucial importance in most of Shakespeare's plays, and we can find in his works some particularly significant sources of insight into the vital and complex roles of memory. These roles include not only creating identities but also commenting upon issues concerning time and death, as well as voicing diverse reflections upon the dark realms of human consciousness. In The Tempest, Prospero asks Miranda what her remembrance' discerns in 'the dark backward and abysm of time'( $\underline{\text { The }}$ Tempest, I, ii, 46-50). Henry V asks: 'May this be wash'd in Lethe, and

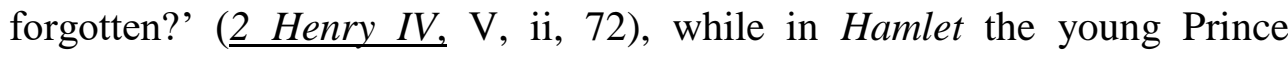
remembers the past happy days with his father and laments in his mourning, uttering in pain the words: 'Must I remember?'( $\underline{\text { Hamlet }}$, I, ii, 143). Reminiscences of the past bring suffering and create a sense of the unendurable. Macbeth implores the doctor to cure Lady Macbeth:

'Canst thou not minister to a mind diseas'd, / Pluck from the memory a rooted sorrow, / Raze out the written troubles of the brain, /And with some sweet oblivious antidote/

Cleanse the stuff'd bosom of that perilous stuff / Which weighs upon the heart?' (Macbeth, V, iii, 39-44).

In Hamlet, in her mad scenes, Ophelia offers 'rosemary for remembrance'. Her songs reveal a mind totally distraught and full of 
fragmented memories of past trauma. Her fragmented speeches and songs reflect the disorder and chaos in her mind and its rupture with present time and external reality. Just as in the case of Lady Macbeth's mind, from which 'the rooted sorrow' could not be uprooted, so her past traumatic memories and fears cannot be erased from Ophelia's suffering mind. Both characters live within their own consciousness and imaginative world, tossing in the ocean of reminiscences of the past. My paper will deal with the mnemonic fragments of human consciousness reflecting past traumas and will examine the cases of both Ophelia and Lady Macbeth from a feminist reading of women.

In his essay "Madness and Memory" Jerome Mazzaro alludes to Edward Grimestone's Introduction in which he states that 'memory relies on the proper registering, storage, and retrieval of forms' and adds that 'memory serves the sensitive soul knowledge by representing continually unto the common sense the forms which are consigned unto her' (cited in Mazzaro 1985:97).

In his plays Shakespeare introduces both Ophelia and Lady Macbeth as people whose memories seem to be disrupted by psychic breakdown madness in Ophelia's case and somnambulism in that of Lady Macbeth. Ophelia has lost all contact with outside reality and lives in a world of her own in which fragments of the past seem to be disturbing her psyche and consciousness, whereas Lady Macbeth appears to be caught up in a particular moment of a past

memory, going over the past trauma in minute detail in her guilty conscience. Mazzaro compares the feigned madness of Hamlet and Edgar with the mental states of Ophelia and Lear and states that "the differences between the mental states of Ophelia and Lear reveal not only how much a 
Simonidean memory system based upon correspondences between a microcosm and macrocosm has taken root but also how, by positing an intermediary ordering reference point in a demicosm (much like the interior ordering vanishing points of Renaissance painting), a basis for wordly or human understanding is created." (Mazzaro 1985:98) Shakespeare makes use of the Elizabethan notion of multiple perspective, as he juxtaposes different cases concerning human madness. In the play, when the Gentleman explains to Horatio and Gertrude the present state of Ophelia's insanity, he says: 'Her speech is nothing, / Yet the unshaped use of it doth move/ The hearers to collection' (Hamlet IV, v, 7-9).

Ophelia's outer behaviour also reveals her inner agony as she beats her breast, spurns enviously at straws and speaks things in doubt. Her words do not signify anything to other people; what Ophelia in her disturbed mind wants to express as madness interrupts the contact between memory and meaning within her sensitive and fragile psyche. Her speech does not permit people to understand what she has in her consciousness, so her words are understood as nonsense because there is no logical sequence to them but only the suffering in her mind coming out in fragments. She seems to be speaking in her imaginative mind to someone who is not there, or from time to time she sees some illusions or fragments of the reminiscences of her past life which give a new dimension to her inner sorrow. She has totally lost contact with the reality of the present world but lives within the fragments of the traumatic memories which flow incessantly within her mind. Madness can be described, in Mazzaro's approach, as a closing off of one's self from others and from one's past through a breakdown in the verba-res bond (Mazzaro 1985:101). 
As Frances Yates notes in The Art of Memory, the artificial memory structures are usually preserved in the brain even in insanity. Ophelia remembers certain snatches of songs which are locked in her artificial memory (Yates 1966:114-115). Timothy Bright in his 1587 Treatise of Melancholie argues how melancholy "dulls" the receptivity of memory and the image it stores. Bright explains both the causes and the symptoms of melancholy, which involves the interactions between the soul, the mind, the passions and the body and is caused by spiritual doubt or a sense of sin which comes from the "incomprehensible and inexpressible loss of God's favour" (Bright 1586:185), or is sometimes caused by unreasonable sadness or natural depression coming from the unnatural excess or combustion of the cold dry humour or black bile. Elaine Showalter defines Ophelia's case as follows:

\footnotetext{
Clinically speaking, Ophelia's behaviour and appearance are characteristic of the malady the Elizabethans would have diagnosed as female love-melancholy or erotomania. ( Showalter 1992:284)

In Elizabethan slang, 'nothing' was a term for the female genitalia... To Hamlet, then 'nothing' is what lies between maids' legs, for, in the male visual system of representation and desire, women's sexual organs, in the words of the French psychoanalyst Luce Irigaray, 'represent the horror of having nothing to see'... Deprived of thought, sexuality, language, Ophelia's story becomes the story of $\mathrm{O}-$ zero, the empty circle or mystery of feminine difference, the cipher of female sexuality to be deciphered by feminist interpretation. (282)
}

In The Divided Self, R. D. Laing, while assessing the case of Julie Doll, states that "Julie's self-being had become so fragmented that she could best be described as living a death-in-life existence in a state approaching chaotic nonentity" and adds that "uncanny" praecox feeling was described 
as of being in the presence of another being and yet feeling that there was no one there" (Laing 1990:195). Laing evaluated Ophelia's case as a "Dementia Praecox" which is a form of schizophrenia seen in young people at the conclusion of chronic psychosis. He claimed that:

In her madness there is no one there. She is not a person. There is no integral selfhood expressed through her actions or utterances. Incomprehensible statements are said by nothing. She has already died. There is now only a vacuum where there was once a person. (Laing 1990:195)

Laing's diagnosis of Ophelia's case shows that Ophelia is an absence, a voice with no sense or meaning, reflecting no selfhood.

Shakespeare dramatises Ophelia's insanity through a peculiar language that includes mnemonic fragments of the past, embedded popular songs in a disordered form, and bawdy remarks, as well as through physiological symptoms of madness: sudden changes of gesture and bodily movements, uncontrollable restlessness and agitation, and obsessive repeated spasms of pain. Ophelia's fragmented and alienated speech conveys transformation and loss which comprises lost love, lost chastity and death. Her discourse reveals that she is responding to voices that are not present. Laertes, deeply shocked on witnessing her state of madness as she distributes the flowers to those who are there, states her desperate condition as 'A document in madness - thoughts and remembrance fitted!' ( IV, v, 172-3)

Carol Thomas Neely in her essay "Documents in Madness" explains that 'the context of her disease, like that of hysteria later, is sexual frustration, social helplessness, and enforced control over women's bodies' (Neely 1996: 84). 
Most recently, some feminist critics, including Gabrielle Dane in "Reading Ophelia's Madness", have pointed to her loss of identity after the removal of male dominance over her life. Dane argues that 'motherless and completely circumscribed by the men around her, Ophelia has been shaped to conform to external demands, to reflect others' desires' (Dane 1998:406). She is Polonius' pawn who can be loosed upon her lover. She is Laertes' chaste sister who has promised to keep his advice secret in her memory by locking it and giving the key to her brother. She is Hamlet's beloved who is confused with the image of Gertrude and described as being, like her, a prey to sexual corruption. According to Dane, when the patriarchal and male authority upon her identity is taken away, poor Ophelia seems to have gained a voice of her own in her songs of madness which reveal her liberation from the repression of male authority. Dane argues that 'Madness releases Ophelia from the enforced repressions of obedience, chastity, patience, liberates her from the prescribed roles of daughter, sister, lover, subject' (Dane 1998:412). But with the disappearance of patriarchal authority, the male dominance in her life, Ophelia's identity is totally lost in fragments; as Laing has stated, there is no self left. Claudius expresses her condition as follows: 'Poor Ophelia / Divided from herself and her fair judgement,/ Without which we are pictures, or mere beasts' (ㅂamlet IV, v, 84-86).

Neely suggests that 'Ophelia in her mad scenes serves as a double for Hamlet during his absence from Denmark' (Neely 1996:82). In literature, according to Lacan's approach, the double hollows out the real, revealing its absence, by transforming the relations between the imaginary and the Symbolic. The double is a soul, a shadow or a mirror reflection that 
exists in a dependent relation to the original, pursuing the subject as a second self.

As Otto Rank states in the chapter of Beyond Psychology entitled "The Double as Immortal Self", the double appears as precisely the opposite, a reminder of the individual's mortality, indeed "the announcer of death itself' (Rank 1958:73).

Elaine Showalter points to the ambiguous nature reflected in Ophelia's character Composition, which is deliberately left in obscurity by Shakespeare himself:

\begin{abstract}
Ophelia dresses in white, decks herself with 'fantastical garlands' of wild flowers, and enters, according to the stage directions of the 'Bad' Quarto, 'distracted' playing on a lute with her 'hair down singing'. Her speeches are marked by extravagant metaphors, lyrical free associations, and 'explosive sexual imagery'. She sings wistful and bawdy ballads, and ends her life by drowning. All of these conventions carry specific messages about femininity and sexuality. Ophelia's virginal and vacant white is contrasted with Hamlet's scholar's garb, his 'suits of solemn black'. Her flowers suggest the discordant double images of female sexuality as both innocent blossoming and whorish contamination; she is the 'green girl' of the pastoral, the virginal 'Rose of May' and the sexually explicit madwoman who, in giving her wild flowers and herbs, is symbolically deflowering herself... she might either be mad or the victim of a rape; the disordered hair, her offense in decorum, suggests sensuality in each case. (Showalter 1992:284)
\end{abstract}

Once psychoanalytical studies had established Ophelia as an icon of female sexual trauma and the feminists began to regard her madness as the result of sexual intimidation and female victimisation, her death started to be evaluated quite differently. The circumstances of her death had previously been left in obscurity and mystery. Within Shakespeare's text, we are struck by the ambiguous and doubtful nature of what is said about 
Ophelia's death. According to Gertrude's account, it was an accidental drowning, whereas the gravedigger implies that it was a case of suicide. The ambiguity, concerning Ophelia, can also be seen in the earlier source of the play by Belleforest in which Ophelia's briefly sketched figure 'served the essential function of the temptress' (Camati 2006:72).

James Vest regards Ophelia as a conflation of contradictions and a fusion of opposites which combines the image of a sexually alluring siren with that of a violated saint (Vest 1989:49). In the visual, literary and performing arts, Ophelia appears as "a site of memory, fantasy, projection and desire" (Kiefer 2001:12). Those who regard her drowning as suicide interpret it as a rebellious act of resistance against the chains which imprison her within the patriarchal authority, the means through which she gains her own voice of freedom; this would be Gabrielle Dane's view.

In his 1992 production of Hamlet, Marcelo Marchioro attempted to convey the disintegration of Ophelia's psychic identity and her gradual drifting into madness by casting two actresses in the role of Ophelia; one of them stands for the heroine's external, socially constructed "mask" and the second embodies her "Doppelganger", reflecting her inner state of revolt and anger, in other words, the counterpart of the person, the other "I", or the alter ego which is the hidden or veiled aspect of a character's personality. The Brazilian director employed this Brechtian device in order to highlight Ophelia's identity crisis by showing both the face and the mask at the same time on stage. From a psychoanalytical point of view, this device displayed the mental forces of the ego and the id of Ophelia concretely on stage. Ophelia One is manipulated by her father and brother and commanded to distrust her deepest feelings and desires as a female. She appears as an ideal of chaste womanhood, bereft of sexuality, silently subservient and self- 
effacing, whereas Ophelia Two appears as a bare-breasted and barefoot Ophelia, wearing a long, loose dress which highlights her womanhood and sexuality, with flowing, dishevelled hair, displaying emotional and uncontrolled outbursts with a frenzied and lost gaze. In his production, Ophelia Two "takes over the role completely in scenes of madness" which "finally releases her from her socially constructed mask and provides her with an opportunity to voice her concerns that had been 'silenced"' (Camati 2006:77). Marchioro employs a poignant dance of death in which the two selves of the troubled maiden are reconciled during the scene of her death. Marchioro renders the drowning as a suicide ritual and as a rebellious gesture of freeing the soul from its chains. Anna Stegh Camati defines Ophelia's madness and its causes as follows:

Completely circumscribed by male power, she is forced to repress not only her sexuality, but also to efface her identity, constructed exclusively in reference to others, being prevented from healthy spiritual growth and maturation as an individual. Her psychic identity collapses under the excessive strain she has submitted to, resulting in the loss of her sense of reality. (Camati 2006:75)

Lady Macbeth is another of Shakespeare's striking creations. In her he creates another female character who has been disturbed in the depths of her consciousness and conscience and who has been reliving the mnemonic past incessantly in her mind. Robert Munro in his essay "Lady Macbeth: A Psychological Sketch" describes Lady Macbeth in her sleepwalking scene as a spectre and states that what we see on stage is not Lady Macbeth but "her evil counterpart" - "that other self" - which is mostly hidden from the common gaze, and which reveals the dark impulses within the subconscious mind (Munro 1887:30). 
Early in the play Lady Macbeth displays a powerful desire to become Queen by provoking her husband towards murdering Duncan. Her masculinity, seen both in her ambition and in her determined mind, stands in strong contrast to the traditional view of femininity at that time, in which women were considered to be tender, soft and silent. The speech in which she calls forth her evil spirits to stop the functioning of her feminine side links her to Edward Jorden's conception of the relationship between hysteria and witchcraft (see his work The Suffocation of the Mother). Immediately after the murder of Duncan, she tells Macbeth, who comes in with the bloody daggers in his hand, totally overpowered by the shock of the crime he has committed: “The sleeping and the dead / Are but pictures,'tis the eye of childhood / That fears a painted devil" (Macbeth II, ii, 54- 56). Lady Macbeth here displays a masculine-type behaviour, whereas towards the end of the play she is seen to be totally disturbed in her psyche because of the murder of Duncan, which has brought her only a tortured conscience and estrangement from her husband. She is left to suffer in loneliness and silence. Though it seems that she has obtained the object of her desire and has been enthroned as Queen of Scotland with the Scottish crown on her husband's head, she has lost her husband's affection and her intimate relationship with him, so the crown seems to weigh more heavily on her head than before, as it has brought her what she had least expected.

In her nocturnal preambulations she seems to be stuck in the terrible moment of the Crime, which has become an obsessive trauma in the gnawing of her conscience. As she wrings her hands in anguish to try to get rid of the blood spots, she sighs in despair, saying: "Yet who would have thought the old man to have had so much blood in him?" (Macbeth V, i, 378). "All the perfumes of Arabia will not sweeten this little hand" (Macbeth 
$\mathrm{V}, \mathrm{i}, 48-9)$. As the physician and the nurse remark, her eyes are open, but the sense is shut. As Munro states, "she had no outlet at all for the misery that was growing at her heart" (Munro 1887:34). Sadly, she had to bear it in all its secret reality. The mnemonic fragments of the night when Duncan was murdered will forever be engraved upon her subconscious mind. The memory of the crime remains obsessively alive and highly damaging and disturbing in her consciousness. The gnawing of her conscience drives her into sleepwalking. Before the appearance of Macbeth with the bloody daggers in his hand, Lady Macbeth confesses an inner truth about herself when she says: "Had he not resembled / My father as he slept, I had done't" (Macbeth II, ii, 12-3). Here we see the Symbolic described by Lacan under the name of "au nom du pere".

When she conjures up her evil spirits, Lady Macbeth negates her maternal side and her femininity. She displays a strong desire to develop a hard-hearted masculine nature when she asks Nature to change the milk of her womanly breasts into gall. Her uncontrollable ambition and demanding nature transform her into a figure of cruelty and destruction when she utters the words: "I have given suck, and know / How tender 'tis to love the babe that milks me;/ I would while it was smiling in my face/ Have plucked my nipple from his boneless gums/ And dashed the brains out, had I so sworn as you" (Macbeth I, vii, 52-56).

Freud diagnosed her sickness by stating that "Lady Macbeth's illness ... could be explained directly as a reaction to her childlessness" (Freud 1955:322). Isador Coriat agrees with Freud, stating that "Lady Macbeth's hysteria and somnambulism arose from a repressed wish for a child" (Coriat 1914:20). Joanna Levin, in her essay "Lady MacBeth and the Daemonologie of Hysteria", discusses Edward Jorden's The Suffocation of the Mother and 
states that "Created three years after the publication of Jorden's etiology, the figure of Lady Macbeth herself intensifies the perverse doubleness of the Mother" (Levin 2002:38). Pointing to Dympna Callaghan's view that Lady Macbeth enacts the transformation of the witch into the hysteric, Levin argues that Lady Macbeth occupies an intermediary place in the play as "she resists a splitting of the demonic matriarch and the secular mother" and "her narrative development figures the many continuities between the witch and the hysteric" (Levin 2002: 38). Just as in Edward Jorden's approach to "hysterica passio" and the vicissitudes of the Mother in his treatise The Suffocation of the Mother, Levin gives the figure of Lady Macbeth as the typical exemplar of disorderly femininity emerging from the hystericizsd woman and the witch (Levin 2002: 45).

\section{Conclusion}

To conclude, we may state that memory and mnemonic fragments within the human consciousness reveal what is kept secret in the characters' subconscious. Shakespeare, in his depiction of both Ophelia in Hamlet and Lady Macbeth in Macbeth, deals with the importance of memories as well as with the symptoms of disturbed consciousness and signs of insanity in these female characters, which reflect trouble and suppression in the sexual identity of the person within a patriarchal society.

\section{References}

Adelmann, Janet. 1992. Suffocating Mothers: Fantasies of Maternal Origin in

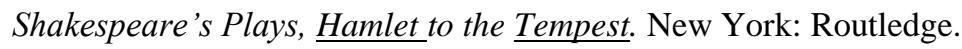

Bright, Timothy. 1586. A Treatise of Melancholie. London: Thomas Vautrollier.

Callaghan, Dympna. 1992. "Wicked Women in Macbeth: A Study of Power, Ideology, and the Production of Motherhood" in Reconsidering the Renaissance: Papers from 
the Twenty-First Annual Conference. Mario A. Di Cesare (Ed.). New York: Binghamton.

Camati, Anna Stegh. 2006. “Rereading Shakespeare's Ophelia: Marcelo Marchioro’s Performance Aesthetics" Multicultural Shakespeare: Translation, Appropriation and Performance. Lodz University Press, V(03):69- 80.

Coriat, Isador. 1914. Abnormal Psychology. NewYork: Moffat, Yard and Company.

Dane, Gabrielle. 1998. "Reading Ophelia's Madness" Exemplaria. 10(2): 405423.

Freud, Sigmund. 1955. The Standard Edition of the Complete Works of Sigmund Freud. Vol 14, James Strachey (Ed.). London: The Hogarth Press.

Jorden, Edward.1603. A Briefe Discourse of a Disease Called the Suffocation of the Mother. London: John Windet.

Kiefer, Carol Solomon. (Ed.) 2001. The Myth and Madness of Ophelia. Amherst: Amherst College Press.

Lacan, Jacques. 1977. Ecrits. New York: Norton.

Laing, R.D. 1990. The Divided Self: An Existential Study in Sanity and Madness. London: Penguin.

Levin, Joanna. 2002. "Lady MacBeth and the Daemonologie of Hysteria" ELH 69(1) (Spring, 2002), Johns Hopkins UniversityPress, pp. 21-55.

Lidz, Theodore. 1975. Hamlet's Enemy: Madness and Myth in Hamlet. Madison, Connecticut: International Universities Press.

Mazzaro, Jerome. 1985. "Madness and Memory: Shakespeare's Hamlet and King Lear" Comparative Drama 19(2): 97-116.

Munro, Robert. 1887. "Lady Macbeth: A Psychological Sketch” The Journal of Speculative Philosophy. Pennsylvania State University Press21(1):30-36.

Neely, Carol Thomas. 1991. “'Documents in Madness': Reading Madness and Gender in Shakespeare's Tragedies and Early Modern Culture" Shakespeare Quarterly. 42: pp. 315- 338 .

O’Sullivan, Mary Isabelle. 1926. "Hamlet and Dr. Timothy Bright” PMLA 41(3):667-679.

Rank, Otto. 1958. Beyond Psychology. New York: Dover.

Rickard, John. S. 1999. James Joyce's Book of Memory: The Mnemotechnic of Ulysses. Durham, NC: Duke University Press.

Romanska, Magda. 2005. "Ontology and Eroticism: Two Bodies of Ophelia” Women's Studies 34( 6):485- 503. 
Shakespeare, William. 1951. The Complete Works. London: Collins.

Showalter, Elaine. 1992. "Representing Ophelia: Women, Madness, and the Responsibilities of Feminist Criticism" in Shakespearean Tragedy. John Drakakis (Ed.).. London Longman, pp. 280- 295.

Showalter, Elaine. 1985. The Female Malady: Women, Madness, and English Culture, 1830-1980. Harmondsworth: Penguin.

Vest, James M. 1989. The French Face of Ophelia from Belleforest to Baudelaire. Lanham: University Press of America.

Vico, Giambattista. 1984. The New Science of Giambattista Vico. Translated by Thomas Goddard Bergin and Max Harold Fisch. Ithaca: Cornell University Press.

Yates, Frances. 1966. The Art of Memory. London: Routledge \& Kegan Paul.

Zivkovic, Milica. 2000. "The Double as the "Unseen" of Culture: Toward a Definition of Doppelganger" Linguistics and Literature 2(7):121-128. 